УДК 82.-1

DOI $10.17223 / 24099554 / 2 / 6$

\title{
Т.П. Шастина
}

КНИГА Г.М. ПУШКАРЕВА «В ХРЕБТАХ АЛТАЯ» КАК ПРООБРАЗ ОЙРОТСКОЙ ЭНЦИКЛОПЕДИИ (К ВОПРОСУ О ХУДОЖЕСТВЕННО-ИДЕОЛОГИЧЕСКОМ ВООБРАЖЕНИИ СОВЕТСКОЙ НАЦИОНАЛЬНОЙ ОКРАИНЫ)

В статье рассматривается книга «В хребтах Алтая» Г.М. Пушкарева, одного из идеологов сибирской раннесоветской литературы, как образеи художественно-идеологического воображения советской национальной окраины (Ойротской автономной области). Литературный контекст этого вымышленного травелога интерпретируется как переоткрытие Горного Алтая, закрепляющее за территорией новое название - Ойротия, а позиция автора - как следование областнической традиции в создании образов инородиев и инородческих земель. Ключевые слова: Ойротия; русская литература Сибири, травелог, имагология, энцииклопедизм.

В раннесоветскую эпоху происходит разрыв поступательного движения в художественно-идеологическом воображении Горного (Русского) Алтая, образцы которого были даны научными травелогами XVIII-XIX вв. и далее получили свое развитие в публицистике сибирских областников. Наречение созданной на его территории в 1922 г. административной единицы Ойратией (Ойротией) и, соответственно, проживающих здесь коренных этносов собирательным этнонимом «ойраты» (ойроты) порождает литературный образ «народ без имени» [1. С. 13-19] и в очередной раз делает эту национальную окраину «terra incognita». В этой ситуации все дореволюционные издания о Горном Алтае объявляются «буржуазными», идеологически вредными, морально устаревшими, и в текстах об Ойротии начиная с 1922 г. (с первых публикаций в журнале «Сибирские огни» [2]) происходит литературное переоткрытие ${ }^{1}$ территории, которую можно назвать «периферией периферии». Сложнейшие

${ }^{1}$ К.В. Анисимов, проанализировавший формирование русской литературной традиции в Сибири, пришел к выводу, что «возникавшие на пути становления этой традиции паузы, моменты своеобразного «безвременья» создавали на каждом следующем этапе развития ощущение того, что региональная словесность вновь только нарождается, а опыт, накопленный годами ранее, - не в счет» [3. С. 289]. 
процессы едва закончившейся к моменту юридического оформления национальной автономии в Горном Алтае гражданской войны делают эту территорию завоеванной периферией; в этом статусе нуждающейся прежде всего «в идеологическом переосмыслении и символическом «переименовании» [4. С. 60]. Переосмысление начинается с включения Ойратской (чаще употребляется написание Ойротская) автономной области в состав советских восточныlx территорий, произведенное в соответствии с классификационными критериями национальной политики тех лет [5. С. 40-41]. Риторика культурной отсталости заставляла писателей при взгляде на эту территорию извне и особенно - изнутри сосредоточивать внимание на самом диком, самом отсталом, изображать коренное население как жертву колониальной политики царизма в прошлом и великорусского шовинизма - в настоящем. К концу первого десятилетия существования автономной области складывается довольно значительный корпус посвященных национальной автономии произведений разных стилей и жанров: очерков столичных и сибирских журналистов [6], мемуаров, трудов историков, этнографов; в столичных издательствах выходят художественные произведения [7; 8; 9]; формируется переводческая школа с алтайского языка. Бравурной кодой первого десятилетия автономии становится ойротский выпуск журнала «СССР на стройке» (1932. № 9) с текстом Марка Эгарта (ранее выпустившего книгу об Ойротии с говорящим названием «Переправа» [10]) и фотоснимками М. Альперта и С. Фридлянда, не оставляющий сомнений в том, что в ойротском тексте доминирует идеологема красной нови.

Любые отступления от принципов национальной политики в показе национальной автономии жестоко караются, примером чему может служить история травли Л.П. Мамета, автора исследования об особенностях гражданской войны в Горном Алтае, написанного на основе тогда еще сохранявшихся документов противоборствующих сторон и по воспоминаниям участников [11]. Автор позднее был вынужден признать, что допустил непростительные ошибки в трактовке событий начала XX в. в Горном Алтае и особенно в интерпретации гражданской войны как войны национальной. На фоне множества трагических судеб писавших об Ойротии в 1920-1930-е гг. (П.Я. Гордиенко, Г.И. Гуркин, Н.Н. Зарудин, Л.П. Мамет, И.И. Катаев, П.А. Чагат-Строев и др.) счастливым исключением выглядят успешная писательская карьера создателя первого романа о советской 
Ойротии А.Л. Коптелова [12], а также административно-издательская деятельность Г.М. Пушкарева. Пушкарев в общедоступной форме детской книги первым систематизировал естественногеографические и этнографические сведения об Ойротии [13]. Избегая политических оценок, он фактически разработал основу для написания ойротской энциклопедии, которой так и не суждено было появиться на свет (да и вряд ли кто рискнул бы создавать в тот период областную энциклопедию, памятуя о печальной судьбе Сибирской советской энциклопедии) ${ }^{1}$.

Глеб Михайлович Пушкарев (1889-1961) - заметная фигура в литературной жизни советской Сибири, один из создателей журнала «Сибирские огни», один из идеологов Сибирского союза писателей [15]. Яркий краевед, он много сделал для осмысления феномена сибирской раннесоветской литературы и локуса «Ойротия» в ней. В частности, им создана первая сибирская хрестоматия - «Сибирская новь» [16], где новейшие произведения о Сибири были сгруппированы по хроникально-тематическому принципу (Путь к Октябрю - Октябрьская революция в Сибири - Падение Советской власти - Директория - Интервенты и Колчак - Гражданская война в Сибири - Красная армия - Годы разрухи - Новый быт - Комсомол и пионеры - Сибирский край - Сельское хозяйство - Природные богатства Сибири - Торговля - Кооперация - Народное образование - Туземцы). Символом Ойротии в этой книге становится Чуйский тракт (в книге помещена крошечная справочная статья «Чуйский тракт» и одноименное стихотворение Ильи Мухачева). Заключительный раздел книги ${ }^{2}$, весьма символичен - на фоне «красной нови» отчетливо проступают идеи сибирских областников: в процессе русской колонизации Сибири «туземец был оттеснен», в частности «киргизы оттиснуты в степи по Иртышу, алтайцы и шорцы загнаны в горы, а все лучшее захвачено русскими... Туземцы - основное когда-то население Сибири, в царской России стали чем-то посторонним, лишним, бесправным, забитым народом...» [16. C. 247]. При этом закономерно подчеркивается, что советская власть резко изменила положение - «туземец из презираемого инородца -

${ }^{1}$ Следует отметить, что справочно-энциклопедическое издание, посвященное Горному Алтаю [14], вышло только в XXI в. Данный проект был задуман и осуществлен как книга, влияющая на формирование позитивного имиджа региона.

${ }^{2}$ Текст раздела «Туземцы» можно атрибутировать по Пушкареву как публицистическое осмысление специфики коренного населения Сибири, выполненное на основе одной из первых художественных публикаций этого автора, посвященных алтайцам [17]. 
стал равноправным членом советской семьи. Туземец получил право гражданства, право самоопределения, право организации своего управления, советского строя» [16. С. 248].

Следующая хрестоматия, «Сибирь в художественной литературе», создавалась как «учебное пособие для школы повышенного типа, начиная со школы 2 ступени и кончая вузом», пропагандирующее Сибирь на всесоюзном уровне; на местном же уровне это был стимул «для творческой работы по поднятию культуры Сибири, превращенной Октябрем из царской колонии в равноправную часть РСФСР - СССР» [18. С. 7]. В предисловии Пушкарев, разделяя взгляды основателей советского краеведческого движения, писал, что без истории литературы своего края краеведение будет половинчатым [18. С. 3]. В этом издании было значительно сокращено число тематических рубрик: 1. Туземная Сибирь и сибирская старина. 2. Кандальная Сибирь и приискатели. 3. Крестьянская Сибирь до революции и переселение. 4. Революционное движение в Сибири и гражданская война. 5. Новая Сибирь. Работа по отбору текстов для последней рубрики приводит Пушкарева к выводу, что большинство современных произведений не являются «вполне художественными», в них преобладают публицистические начала. В этой книге ойротская тематика попала в две рубрики - «Туземная Сибирь и сибирская старина» и «Новая Сибирь» (по-прежнему символом окраинного положения Ойротии Пушкарев считает Чуйский тракт трансграничный коридор в Монголию; перепечатывая стихотворение Ильи Мухачева «Чуйский тракт», составитель дал краткую справку об авторе: «Мухачев Илья. Крестьянин. В 1920 г. научился грамоте. Сейчас печатается в газетах и журналах. Обещает развиться в крупный талант» [18. С. 300] ${ }^{1}$.

Если сюжетно-мотивный комплекс первой рубрики хрестоматии был весьма разнообразен (быт и религиозные представления тузем-

${ }^{1}$ Первый сборник И. Мухачева назывался «Чуйский тракт» [19] и открывался одноименным стихотворением, привлекшим Пушкарева соединением колониальных мотивов с мотивами красной нови:

Не купцу ли с хмельного дурмана,

Ослабев на сердце и язык,

Отдавал первейшего барана

За стекляшку светлую калмык? <...>

Но с тех пор прошло дней сивых много,

Красный ветер здесь провеял пыль;

По надбездным пасмурным дорогам

Зацвела совсем другая быль. 
цев Сибири; политика русского капитала в туземной Сибири; отношение туземцев к царским чиновникам; национальный вопрос в царской Сибири; положение туземцев Сибири в дореволюционной России; национальный вопрос в СССР; положение народностей Сибири в настоящее время; Сибирь - царская колония; нравы и быт старой Сибири; мирские начала в сибирской деревне), то о новой Сибири говорить было еще практически нечего, изобрели только три темы: борьба за новый быт; отцы и дети в сибирской деревне; новая деревня.

Перепечатывая свои миниатюры «Младенцы гор» в рубрике «Туземная Сибирь и сибирская старина», Пушкарев предваряет их биографической справкой: «Пушкарев Глеб Михайлович. Родился в 1889 г. в Томске. Детство провел в сибирской деревне, вобрал в себя её дух и быт, что после и стало главным мотивом в его творчестве. Окончил среднюю школу экстерном и поступил в психоневрологический институт, но война не позволила его окончить. По характеру письма - бытовик и детский писатель» [18. С. 30]. По сути, в названных миниатюрах Пушкарев развивает областнический мотив «туземцы - дети природы» (об алтайцах в этом ключе писал, например, Г.Н. Потанин в цикле «В Чемальском тупике», называя их «детьми природы, которые живут в рабстве у своих предрассудков» [20]).

В 1930 г. Пушкарев выпускает собственную небольшую богато иллюстрированную фоторепродукциями и рисунками книгу «В хребтах Алтая: Для детей среднего и старшего возраста», которую можно назвать прообразом популярной энциклопедии об Ойротии ${ }^{1}$. Немудреный сюжет книги Пушкарева с позиций нашего времени воспринимается как совершенно нереальный - трое школьников Виктор Головин, Алексей Петров, Григорий Аламбаев-калмык с проводником отправляются в путешествие по Горному Алтаю, их маршрут пролегает через всю территорию области с заходом на Белуху, спуском в Казахстан и возвращением на пароходе из Семипалатинска в Бийск. Вымышленное путешествие ${ }^{2}$ позволяет вместить в текст значительный объем разнородной информации, а возраст героев и обозначение адресата служит лишь отвлекающим маневром, чтобы избежать бичуемых в тот момент партией уклонов в национализм или великодержавный шовинизм, не говорить, что все беды алтайцев - от русских (что не преминул подчеркнуть А. Копте-

\footnotetext{
${ }^{1}$ Научный очерк об Ойротии вскоре опубликовал Л. Эдоков [21].

${ }^{2}$ Ср. с путевыми очерками А. Коптелова «Золотые горы» [22], «Горными тропами» [23] или с дневником Всесоюзной пионерской экспедиции юных мичуринцев Кованова [24].
} 
лов в своем «Мороке» [25]). Обращение к форме детской книги типологически объяснила М.О. Чудакова, писавшая, что в литературе 1920-1930-х гг. «реальность повседневной жизни - с её тяжелым бытом и прочим - растворялась, выводилась из наблюдения. Начались поиски возможности писать вне конкретного материала текущей жизни, вне реальности современности. Открылись два таких пути - историческая проза и литература для детей...» [26. С. 247].

Собратья по цеху рассматривали книгу Пушкарева как неудачный пример произведения для детского чтения, о чем свидетельствует статья Клеопатры Гайлит «Заметки о сибирской детской литературе» [27] ${ }^{1}$. Писательница высоко оценивала образный потенциал Горного Алтая: «Богатейший во всех отношениях участок Сибири Алтай - уже давно привлекает к себе внимание писателей, в том числе и детских. Для писателя, как и для художника, Алтай - неисчерпаемая сокровищница. Даже объективный фотограф с маломальским художественным чутьем может найти на Алтае потрясающую по красоте «мертвую натуру», не говоря уже о неиспользованных в этом отношении возможностях кино. Чтобы омертвить Алтай, надо особое умение, особый талант» [27. С. 151]. Его-то и обнаружила Гайлит у Пушкарева, «прирожденного сибиряка», «изъездившего и исходившего Алтай вдоль и поперек еще смолоду». $\mathrm{C}$ позиций критика она заявляет, что книга «В хребтах Алтая» в список художественных попала случайно. «Это - сухие выписки из десятка учебников географии и дневников «аполитичных» сибирских ботаников, геологов, энтомологов «времен очаковских и покорения Крыма» [27. С. 151]. Гайлит категорически требовала, чтобы Пушкарев перешел «к показу такой Сибири, такого Алтая, которые встают в сознании каждого школьника как определенная, с большим удельным весом часть СССР» [27. С. 152].

На наш взгляд, негативную оценку 1933 г. мог спровоцировать отзыв ойротского идеолога П.Я. Гордиенко о книге Пушкарева: «Нельзя безнаказанно протаскивать на четырнадцатом году революции утверждение, что Чорос-Гуркин, Сары-Сеп-Конзычаков, Ток-

${ }^{1}$ К.Н. Гайлит выпустит историческую повесть для детей «Грозный перевал» [28], написанную на основе воспоминаний почитаемого в советскую эпоху героя гражданской войны в Горном Алтае И. Долгих. Это идеологически «правильное» изложение, пожалуй, самого трагического эпизода из истории гражданской войны в горах Алтая - «снежного похода» и гибели отряда есаула Кайгородова; А.Л. Коптелов, упоминая о том, что К.Н. Гайлит как жена «врага народа» была репрессирована, ошибочно писал, что набор этой книги был рассыпан [29]; позднее текст был переиздан с послесловием горноалтайского историка С. Пахаева [30]. 
машев и Тибер-Петров, бывшие вдохновители контрреволюционной каракорумской авантюры, являются борцами за существование алтайца» [1. С. 10]. В предисловии к своей «Ойротии» Гордиенко сетовал на отсутствие современных (т.е. идеологически правильных) книг о регионе, замечая, что «старые дореволюционные издания переиздаются и продолжают оставаться, как незаменимые справочники об Алтае. Быстро расхватываются книги проф. Сапожникова, Верещагина, Крылова, Пилипенко. Но все это материал устаревших обследований. Многие из них не отвечают истинному лицу современной растущей и крепнущей Советской Ойротии. Однако других книг об Ойротии нет» [1. С. 9].

Примером переработки в нужном идеологическом ключе дореволюционной научно-популярной книги может служить переиздание труда проф. В.В. Сапожникова «Пути по Русскому Алтаю» (Томск, 1912), подготовленное Сибкрайиздатом [31]. В предисловии были названы причины переиздания данного текста: возрастающий интерес к изучению Алтая, организация многочисленных экскурсий, отсутствие «руководящей» литературы» для исследования Алтая. Утверждалось также, что издание 1912 г. значительно устарело «в части общего облика жизни Алтая и цифровых данных», указывались новейшие источники, на основе которых были сделаны необходимые уточнения, в частности новейшие справочники [32, 33] и данные сибирской плановой комиссии. Основную работу по редактированию второго издания выполнила дочь профессора Н.В. Сапожникова; среди тех, кто трудился над подготовкой книги к печати, был назван и Г.М. Пушкарев.

Написанный Г.Н. Потаниным специально для книги В.В. Сапожникова очерк «Население» был заменен компилятивным очерком «Ойратская автономная область», в котором угадывается рука Г.М. Пушкарева, «замаскировавшего» статистикой и новым названием базовый текст Потанина, что и позволило частично сохранить его - при условии, что партийные цензоры были людьми малообразованными и внимательно в содержание не вчитывались. Новый очерк начинался с констатации этнического своеобразия Ойротии: «Помимо природных особенностей горной страны, Русский Алтай своеобразен и по основному составу своего туземного населения, объединенного в особую Автономную область ойратского народа» [31. С. 14]. Далее следовала статистика: «Территория Ойратской области равняется 90.689 кв. километров. По национальному составу 
население области слагается из 54,57 \% русских, 41,99 \% алтайцев, $2,96 \%$ киргизов и $0,48 \%$ прочих» [31. С. 15] и указывалось, что алтайцы (не ойроты, не калмыки) в племенном отношении разделяются на собственно алтайцев и черневых татар, сойотов (монголов), теленгитов, телеутов, кумандинцев, туба, т.е. приводились самоназвания коренных этносов.

С этой обновленной статистики и начинается первая глава книги Г.М. Пушкарева «В хребтах Алтая», названная «Неожиданное путешествие»: «Виктор читал по карте “Территория Ойротской автономной области занимает 90689 кв. километров. Население 86971 человек, распределяющихся по 10 аймакам и 690 нас. пунктам"» [13. C. 3]. Школьники подсчитали, что на 1 кв. километр в Ойротии приходится меньше одной души, и это привело их в восторг: «Слышь, ребята, а в Германии на 1 кв. километр приходится 134 души, а в Бельгии - 256 и в центральной части РСФСР 20 душ. Вот это я понимаю! Хорошая страна! Горы, озера, ледники...» [13. С. 4].

Не имея возможности разместить в книге цветную карту территории, Пушкарев прибегает к её описанию: «Карта переливалась коричневыми красками. От бледного она перебегала почти к черному и так же быстро спускалась на светлую. Синие жилки обняли, сцепили темные пятна со щупальцами во все стороны, связали их, стеклись сами в жгуты и протянулись двумя голубыми лентами к северу. Ряд голубых пятен, больших и малых, васильками выглядывали среди коричневых пятен. Это горные озера разбросались по всей карте, и на темных коричневых пятнах белелись полоски снегов - ледники» [13. С. 4].

«Продвинутые» советские школьники, стоя у такой карты, понимают, в каких условиях им предстоит провести лето, а потому должным образом собирают снаряжение. В описании экипировки экскурсантов отчетливо просматривается рекомендательный список В.В. Сапожникова [34. С. 166-167], а не ассортимент улалинских торговых точек - «...на вьючных лошадях, в сумах было достаточно набито всякой провизии. Тут сухари, мука, консервы, копченые колбасы, сгущенное молоко, аптечка, посуда разная, спирт, вино на всякий случай, ножи, топоры, таганы, починочный материал, а у седла каждого мешки с бельем, подушкой, одеялом и шубой» [13. С. 4].

Первая остановка в пути - селение Чемал, излюбленное место отдыха сибиряков с конца XIX в. ${ }^{1}$. Чемал необходим был Пушкареву

${ }^{1}$ Предшественниками Пушкарева в описании этого локуса в раннесоветской литературе были П. Казанский [35] и М. Шкапская [36]. Последняя назвала курортное местечко 
для создания общего представления о горах - что в одинаковой степени было важно и для сибирского, и для столичного читателя: «Кругом горы. Они цепями обступили Чемал и уходили в бесконечную даль, поражая обилием красок. Впереди темно-зеленые, дальше синие, там туманно-синеватые, розовые, а за ними белые шапки ледников. И далеко в туманной дали белела, извиваясь, Катунь. Катунь в диком беге налетала на скалы, рвала их, бешено бросалась в сторону, чтобы опять наскочить с другой стороны. Она как будто кричала, воя, бесновалась...» [13. С. 5].

Этот горный пейзаж отчетливо напоминает картины Н.К. Рериха и Г.И. Гуркина, подобное впечатление усиливается в книге пейзажными фотоснимками. Река в описании - не просто элемент экзотического пейзажа, а «гидроресурс» (в отличие от П. Гордиенко, который планировал «втянуть Алтай в эксплуатацию» уже во второй пятилетке и писал, что в деле энерговооруженности Кузбасса БиеТелецкая гидростанция произведет «целый промышленный переворот», давая не менее полумиллиона киловатт [1. С. 136], Г. Пушкарев упоминает о планах использования энергоресурсов Катуни: «Там в прошлом году делали опыты и нашли, что силовая станция Тельдекпеня может поднять половину двигателей Сибири. В Сибири двигателей на 47 тысяч лошадиных сил, а Тельдекпень может дать 42 тысячи» [13. С. 5] $\left.]^{1}\right)$.

Сибирская слава местечка Чемал начиналась с деятельности православной миссии, оно слыло еще и учебным центром в горах Алтая, поэтому закономерно здесь у Пушкарева появляется новый персонаж - учитель-естествовед Александр Иванович. Он сообщает путешественникам-ученикам массу статистико-экономической краеведческой информации, например: в Чемале «109 хозяйств и 756 жителей, а дачников съезжается сюда до 300 и более за раз. Да еще вот сюда по хребту есть дом отдыха, куда приезжают рабочие и служащие из разных городов Сибири. Дом приспособлен на 100 коек» [13. С. 7]; «...у нас 109 дворов и около 70 из них - алтайцы. А разве заметно? Дома, как у русских, и тип почти русский. Они значатся как

«русским Давосом» и практически на этом закончила свой очерк об Ойротии (что должно было после описания шаманских практик символизировать движение дикой национальной окраины к цивилизованному светлому будущему). Заметим, что подобным образом (как островок цивилизации в дикой горной стране) описывал Чемал в романе «Черное озеро» украинский писатель В. Гжицкий [8], ездивший в 1928 г. в Горный Алтай с киноэкспедицией начинающего А. Довженко изучать ойротов.

${ }^{1}$ Чемальская ГЭС была построена в 1935 г. 
черневые татары-алтайцы, но давно уже обрусели, слились с русскими... Все живут по русским обычаям. Занимаются земледелием, скотоводством, пчеловодством. Обработка земли примитивная...» [13. С. 7]; «Чем охотно занимаются, так пасекой. В горных долинах везде заимочки и пасеки. Один Чемал собирает до 5 тонн меда ежегодно. Ну, и промыслы есть. В августе орехи кедровые бьют, охота хорошая. Есть медведи... Горный козел, даже марал встречается... Вообще край богатый. Ну, конечно, значительный доход дают дачники. Их здесь и зовут по-своему - воздушники» [13. С. 8]. Вся эта информация детализируется в процессе экскурсии на Каракольское озеро (тут и технология выращивания маралов в специально загороженных маральниках, и консервация их рогов, и быт старообрядцапасечника, и традиционное для сибирской литературы упоминание о медведях, и технология орехового промысла, и новейшая статистика по мараловодству, пчеловодству, охотничьему промыслу).

Авторские же описания в первой части в основном строятся на основе научных данных по географии, ботанике, зоологии, энтомологии и т.п.; например: «Начиналась таежная полоса. Огромные стволы кедров и лиственниц смешались с мелкой лесной порослью, а трава запутала все. Трава казалась лесом. Пучечники вытянулись в целые деревья со стволом в четверть и более. Под одним листом можно было спрятаться от дождя» [13. С. 12]. «Весь склон и дно завалены сплошь массой разноцветного камня - яшма, кварц, песчаник, грубый гранит. Местами лежали целые друзы кристаллов горного хрусталя, играя радугой на солнце, поражая правильностью, полированностью своих граней» [13. С. 16]. Из всех растений Горного Алтая особое внимание уделяется колбе (черемша - Állium victoriális, лук победный) как весьма ценному продукту питания; бадану (Bergenia) как экономически важному дубильному сырью; кедру (местное название сибирской кедровой сосны - Pinus sibirica) как объекту традиционного орехового промысла.

В чемальских материалах Пушкарева практически отсутствует этнологическая информация (что можно объяснить устоявшимся представлением о цивилизованности этой местности), участники экспедиции надеются почерпнуть таковую «где-то в горах, в затерявшихся аулах туземцев, в горных массивах абайца и казака за Белухой» [13. С. 20]. Автор находит альтернативный способ включения в текст сведений такого рода - через отсылку к этнографическим зарисовкам Г.И. Гуркина, поэтому объектом описания становится 
и селение Анос, бывшее в свое время штаб-квартирой ученых и художников круга Г.Н. Потанина. Не упоминая об этом, Пушкарев формирует представление о Чемале как островке культуры в подглавках «Домик под утесом» и «У художника Гуркина». Фраза учителя, представляющего хозяину - «высокому бритому старикуалтайцу» путешественников, - «Они и не знают, что творится в Горном Алтае» [13. С. 21] - ключевая для понимания ситуации, в которой оказался Г.И. Гуркин по возвращении из эмиграции: если Сибирь приветствовала его, то в Горном Алтае он был предан забвению и как политик, и как художник. Пушкареву важно было подчеркнуть исключительность дарования алтайца Гуркина, его академическую школу. В книге обзор творчества алтайского художника делается через описание мастерской: «Вот огромное полотно «Хан-Алтай», дальше пороги на Катуни, вот камлание, «Корона Катуни», вот ряд бытовых картин алтайцев. Реки, горы, озера, целый каскад красок, солнечных пятен, ярких мазков. Вот лоскутки бумаги, и на них уголь, карандаш, перо оживляют природу Алтая. Вот целая заросль папоротников. Вот алтайцы сидят за котлом, и так без конца ${ }^{1}$. Картины, рисунки, зарисовки. Тут же целая коллекция зарисовок Монголии» [13. С. 22]. Учитель дополняет увиденное биографической информацией и констатирует: «...в совершенно еще дикой некультурной стране мы видим такие таланты. Ведь Гуркин - алтаец, калмык. Он и родился в алтайских горах» [13. С. 22]. В сравнении творческой манеры Гуркина с манерой другого художника-алтайца Н.И. Чевалкова ${ }^{2}$ усматривается искусствоведческий источник [39]. «Чевалков - художник другого уклона. В его творчестве новые песни, новые нотки. Чевалкова не интересуют детали, копийность рисунка, ему важно передать настроение, которое охватывает его, и он передает это настроение гаммой красок, игрой, не гоняясь за сюжетом. ...Судьба его не менее интересна. Он крестьянин из телеутов» [13. С. 23].

Далее Пушкарев называет имена политиков и просветителей, к тому времени уже вычеркнутые из местных исторических анналов, вкладывая их в уста персонажа - алтайца (Аламбаева-калмыка): «Кто написал книгу об Алтае? Сарысеп Казанчаков (так. - Т.Ш.). Кто переводит книги на алтайский язык? - Токмашев. Кто боролся за право существования алтайца? - Доктор Тибер-Петров. - Все на-

${ }^{1}$ Писатель в этом фрагменте основывается на восторженных отзывах томичей о выставках Г.И. Гуркина 1907-1908 гг. [37, 38].

${ }^{2}$ Николай Иванович Чевалков (1892-1937), живописец, график, член общества художников «Новая Сибирь». 
ши, алтайцы-калмыки» [13. С. 24]. В этом контексте упоминается и И.С. Алагызов - Пушкарев предвидит его судьбу - до 1937 г. остается совсем немного...

Распрощавшись с учителем, школьники из Аноса направляются по горной дороге в Мыюту, на Чуйский тракт, по аналогии с шелковым путем образно названный в книге «шерстяным путем». Это «главная жила, по которой течет шерсть из Монголии в СССР, где идет торговля с Монголией» [13. С. 25]. В книге кратко характеризуются населенные пункты вдоль тракта: Шебалино («Когда-то богатое, торговавшее с Монголией село, служившее перевалом между Монголией и Бийском, поистрепалось, похудало, осунулось и потеряло свое величие. Купец исчез, ему нечего стало делать, вся торговля перешла в руки государства, которому не требовалось перевалочного пункта, и Шебалино свернулось в деревушку, забив лишние дома, избы, сократив богатеев-купцов» [13. С. 25]) и Топучая («Сеном и живут, хлеба своего нет, а сено - лучше не надо. Сытно живут, опять же ореху тут на перевале много, охота...» [13. С. 26]).

Подъем на Семинский перевал и открывающиеся с него картины наводят на разговор о варварской рубке лиственницы ради сбора серы - жевательной смолки, а далее - на рассуждения о лиственнице как строительном материале и о лесном богатстве области. Проводник рассказывает, как опять-таки варварски вырубают и сплавляют лес в прителецкой тайге: «Ох, и леса здесь хороши. Сколько этих лесов спускают по Бии, по Лебеди, Убе... и не перескажешь. Прорубят просеку прямую с горы, и пускают по ней лес. И веток не рубят. Как упадет вниз, так и попрет без задержки. Так, скажи, пожалуйста, от веток и следов нет, словно их и не было. Сорвет все, счистит, и лесинка, как именинница, внизу ляжет. А там ловят и на лошадях к реке. Плоты ладят и - пошло...» [13. С. 27]. «Рубят, рубят, а разве его изведешь. Век прожить не изведешь, страсть его сколь, а только зверь убывает, с лесом уходит дальше...» [13. С. 28].

Вершина перевала описана как географический водораздел (т.е. приведена справочная информация о высоте над уровнем моря, названия долин и рек) и как граница между пространством настоящего и прошлого (между Ойротией советской и этнографическим Горным Алтаем). Встреча в пути с агентом по заготовке скота позволяет расширить содержание рассказом о ближайшем соседе Ойротии - Монголии. 
За Семинским перевалом начинается в книге традиционное для горно-алтайского научного травелога «этническое пространство» алтайцев (со времен Г.И. Спасского выполняющих функцию собственно литературных «калмыков», т.е. инородных и инославных, к тому же еще и во времена Пушкарева все еще калмыками и называемых), в котором персонажи-путешественники ведут себя как истинные этнографы: идут к туземцам с подарками, при приветствии принимают ритуальные трубки и произносят обязательные слова о новостях. В этой части книги подробно описаны детали жилища (аил снаружи и внутри), костюма («калмыки, несмотря на жаркий день, сидели в шубах. У иных они были богатые, обшитые бархатом, с воротниками и опушками из шкур и на подкладке лисий мех. И все это было грязно, измазано, засалено, кое-где виднелись следы дегтя. Из расстегнутых шуб выглядывали замызганные, почерневшие от грязи рубахи» [13. С. 36]. Быт, обычаи (например, умыкание невесты), специфика коммуникативного поведения, хозяйственная деятельность алтайцев-калмыков как этнологическая составляющая книги Пушкарева напоминают известный очерк Г.Н. Потанина [40], отличаясь от него принципиально лишь идеологемой красной нови указанием на разомкнутость горного пространства: «Каменные громады пропустили жизнь, ту, которая идет за гранью алтайских гор, и в алтайских аилах появилась книга, газета, в селах алтайские школы есть, избы-читальни, и молодняк начинает втягиваться в новую жизнь. Идет она медленною тихо, но твердо и упрямо... В горных хребтах вырос новый человек... Но этот человек еще слаб, у него мало сил, его окружает таежная глушь» [13. С. 45].

Символом глуши традиционно для сибирского текста является образ шамана (по-алтайски - кама). Путешественникам позволяют издалека наблюдать за ритуалом камлания и жертвоприношения. Кровавая жертва описана довольно натуралистично: «Лошадь уронили и перевернули на спину. Она билась, но люди крепко держали её руками. Подошел кам, зазвучал бубен, и за веревки, привязанные к ногам лошади, люди бросились тянуть в разные стороны. Ноги со шкурой были выдернуты из живого тела. На длинном шесте повисла высоко в воздухе кожа убитой лошади» [13. С. 47]. Но в отличие от известных этнографических описаний шаманского жервоприношения напряженность происходящего снимается небольшой подглавкой «Кам сплошал» - больной скончался. 
Этнографические детали были включены в текст для формирования образа «страна прошлого». Переход героев из страны прошлого в сказочную страну символически осуществляется в процессе чтения книги А. Караваевой «Золотой клюв» $[41]^{1}-$ из Теньги путешественники отправлялись в Уймон, в оценке Пушкарева воссозданный Караваевой как «сказочная страна, в которой скрывались беглецы от гнета царского самодержавия» [13. С. 48], где жили раскольники и где находилось таинственное Беловодье.

Чтобы попасть в эту сказочную страну, необходимо было преодолеть Ябоганский перевал. Горные перевалы в книге Пушкарева служат границами воображаемых стран (т.е. на протяжении всего текста работает первоначальное сравнение плотности населения Ойротии с плотностью населения европейских стран, косвенно указывающее на традиционное для горно-алтайского текста русской литературы измерение величины этого горного пространства «в странах», а не в квадратных километрах («...из русского Алтая можно выкроить целых три Швейцарии» [44. С. 193]), а восклицание «хорошая страна» выполняет роль рефрена.

Образ сказочной страны расширяется за счет описаний сказочной красоты Девичьих плесов на реке Кумир и былых сказочных богатств Каргонских каменоломен - ради них путешественники совершили незапланированный поход за границу Ойротии. «Бурный Каргон оброс весь каменными громадами красной яшмы и порфира, а у самого берега вытянулся темный хвойный лес. Все казалось чемто волшебным, сказочным: эти стены из цветных камней, зелень лесов и бурный поток» [13. С. 54]. «Изделия колыванских заводов славились по красоте отделки на весь мир. Недаром часть их цари дарили иностранным государствам. Колыванские вазы стоят в Париже, Лондоне и других мировых столицах» [13. С. 55]. Правда, сказочность образа тут же и снижается: «Еще до революции заводы замерли, а сейчас и совсем прекратили свое существование»- никак не вяжется такая роскошь с фотоснимками аилов и пригонов для скота [13. С. 50] и с описаниями высокогорной абайской степи, где «степная дорога разнообразилась насыпными курганами и каменными бабами - памятниками древней старины» [13. С. 55].

\footnotetext{
${ }^{1}$ Книга А.А. Караваевой - единственное упоминаемое Пушкаревым художественное произведение с алтайской тематикой. Его популярность значительно возросла после выхода одноименного фильма, снятого на Кавказе (!), весьма невысоко оцененного сибиряками («фильм слабее в общем слабой повести А. Караваевой» [42]), но широко использовавшегося в политико-просветительской работе тех лет [43].
} 
Уймон описывается как место компактного проживания кержаков-старообрядцев - «тут ихнее самое гнездо»: «Крепкие хозяйственные дома с пригонами, поветями, стайками, богатые скотом, лошадьми. Наличники окон выкрашены яркими красками, такие же двери. Внутри избы чисто выбелены стены, деревянные части раскрашены разноцветными красками. В углу целый иконостас с лампадками и белыми полотенцами вокруг икон» [13. С. 56-57]. Здесь живут «большебородые крестьяне, в овчинных или кошемных шапках, с большими подстриженными в кружок волосами» [13. С. 57]. Только один раз в книге при описании старообрядческих порядков звучит одно из самых распространенных слов политического словаря той эпохи - кулак (о кержацких наставниках [13. С. 58]).

Из Уймона путь экспедиции лежит к истокам Катуни, на Белуху. Вынося за скобки нереальность такого путешествия для детей ${ }^{1}$, укажем, что природные объекты (озеро Тайменье, седло Белухи, ледник Геблера) были описаны по упоминавшейся книге В.В. Сапожникова «Пути по русскому Алтаю». Решая задачу обновления информации о регионе, Пушкарев уточняет, что за 30 лет со времени пребывания на Белухе Сапожникова «ледник отступил на 552 м» [13. С. 65].

Прощаясь с «ойротским Алтаем», Пушкарев снова описывает панораму гор. Если в начале путешествия его герои смотрят на горы снизу вверх, то в финале - сверху вниз, и перед ними расстилается «целое море гор - синие, лиловые, зеленые, скалистые, серые и коегде белые шапки снегов. Отсюда синими жилками текут горные потоки» [13. С. 68].

Возвращаются герои Пушкарева домой через бассейн Иртыша, выйдя сначала на Рахмановские озера (гл. «Костыли на кедрачах») ${ }^{2}$, затем на границу с Казахстаном, в Катон-Карагай, далее - по Бухтарме с плотогонами - на Иртыш, оттуда пароходом - до Бийска, а из Бийска на подводах - в Улалу.

В пути герои Пушкарева постоянно вели наблюдения, собирали коллекции и гербарий, описывали их, т.е. действовали по указаниям проф. Сапожникова, начинавшего «Пути по русскому Алтаю» таким

${ }^{1}$ Но реальностью позднее стало восхождение на Белуху группы из 100 человек в идеологической акции, получившей название альпиниады [45], в которой принимал участие А.Л. Коптелов, использовавший этот сюжет для создания произведений разных жанров: дневник участника альпиниады - «Белуха» [46], очерки на основе дневника «В горах Алтая» [47], повесть «Снежный пик» на основе дневника [48].

${ }^{2}$ География этой части маршрута совпадает с финальными главами книги Д. Стонова «Повести об Алтае» [49]. 
предисловием: «Быть на Алтае просто туристом - слишком роскошно для туриста и слишком мало для Алтая. Горная страна не исследована во всех деталях даже в ближайших частях; всякий путешественник, и не имеющий специальной подготовки, может привести оттуда новые данные, хотя бы о топографии посещенных местностей, о быте населения, качестве дорог и т.п. Вот почему, принимаясь за обработку этой книжки, я рассчитывал, что она окажется полезной и ученому, и туристу, обоим давая сведения об условиях передвижения и наталкивая второго на материал для наблюдения. Обращаясь к туристу, я настоятельно рекомендую не расставаться с записной книжкой, внося туда все, что обращает на себя внимание» [34. C. I-II]. Следуя этому совету и соотнося собственные впечатления с известными публикациями о Горном Алтае, Пушкарев создал основательный ойротский справочник, к которому применима характеристика, данная в свое время Г.Н. Потаниным трудам В.В. Сапожникова об Алтае: «...его путевые очерки... написаны в увлекательной форме простым и доступным для всякого языком. ... Алтай представляется в обаянии своей диковеличественной и суровой природы, в обаянии своих величественных красот» [50. С. 2-3].

В заключение попробуем предположить, что партийный руководитель Ойротии тех лет П.Я. Гордиенко придал своей книге об Ойротии форму путешествия ${ }^{1}$ в пику Г.М. Пушкареву. Возможно, полемизируя с ним, он и насытил свой текст сведениями и оценками из новейшей истории Горного Алтая, выдержанными в строгом идеологическом ключе. Судя по ранним высказываниям Л. Потапова, считавшегося одним из главных алтаеведов советской эпохи, Гордиенко должен был именно с ним в паре написать исследование об Ойротии [52], но после расстрела репрессированного партийного деятеля, обладавшего ярким литературным даром, Потапов об этом факте уже никогда не упоминал. Литературный контекст сибирской литературы первого советского десятилетия позволяет утверждать, что, объективно дополняя друг друга, книги Г.М. Пушкарева «В хребтах Алтая» и П.Я. Гордиенко «Ойротия» являют популярную научно-художественную энциклопедическую дилогию, реконструирующую образ Ойротской автономной области как советской национальной окраины, сло-

1 Книга П.Я. Гордиенко как цикл художественных очерков проанализирована Л.Г. Чащиной [51. С. 50-58]. 
жившийся к концу первого десятилетия её существования ${ }^{1}$ в представлении сибиряков. Пространство Ойротии в дилогии попрежнему оставалось экзотическим, но теперь уже советским, а его насельники еще не превратились в советских людей, оставаясь, перефразируя А.С. Пушкина, «друзьями гор»- литературными «калмыками».

\section{Литература}

1. Гордиенко П.Я. Ойротия. Репринт. Горно-Алтайск: «Ак-Чечек», 1994. 141 с.

2. Конзычаков Capb-Cen Л.A. Культурно-исторический очерк об алтайцах: (к вопросу о выделении автономной области «Ойрат» // Сибирские огни. 1922. № 1. C. $109-115$.

3. Анисимов К.В. Проблемы поэтики литературы Сибири XIX - начала XX вв: Особенности становления и развития региональной литературной традиции. Томск: Изд-во Том. гос. ун-та, 2005. 304 с.

4. Анисимов К.В. Парадигматика и синтагматика сибирского текста русской литературы: (Постановка проблемы) // Сибирский текст в русской культуре. Вып. 2. Томск: Изд-во Том. гос. ун-та, 2007. С. 60-73.

5. Мартин Т. Империя «положительной деятельности». Нации и национализм в СССР, 1923-1939 / пер. с англ. О.Р. Щелоковой. М.: Рос. полит. энцикл. (РОССПЭН). Фонд «Президентский центр Б.Н. Ельцина», 2011. 855 с.

6. Шастина Т.П. Горный Алтай в очерках столичных журналистов 1920-х гг.: опыт репрезентации национальной окраины // Журналистский ежегодник. 2013. № 2, ч. 1. С. $43-47$.

7. Абабков И. Зорька. М.: Федерация, 1931. 133 с.

8. Гәиикий В.3. Черное озеро: роман / пер. с укр. П. Опанасенко. М.; Л.: Гос. изд-во, 1930. $344 \mathrm{c.}$

9. Чанский Е. Заваруха: роман. М.; Л.: Земля и фабрика, 1930. 387 с.

10. Эгарт М. Переправа: Алтайские очерки. М.; Л.: Гос. изд-во, 1931. 196 с.

11. Мамет Л.П. Ойротия: Очерк национально-освободительного движения и гражданской войны на Горном Алтае. Репринт. Горно-Алтайск, 1994. $181 \mathrm{c}$.

12. Коптелов А.Л. Великое кочевье // Сиб. огни. 1934. № 3. С. 1-133; 1935. № 3. C. $1-167$.

13. Пушкарев Г.М. В хребтах Алтая. Новосибирск: Сибкрайиздат, $1930.71 \mathrm{c.}$

14. Республика Алтай: краткая энцикл. Новосибирск: Арта, 2010. 366 с.

15. Ким A.A. 120 лет со дня рождения писателя-прозаика Пушкарева Глеба Михайловича (1889-1961) // http://www.ngonb.ru/calendar/article.php?ar=55

16. Сибирская новь: Хрестоматия по истории революционного движения в Сибири за 10 ле / сост. Г. Пушкарев; под ред. А. Ансон. Новосибирск: Сибкрайиздат, 1927. $255 \mathrm{c}$.

17. Пушкарев Г.М. Младенцы гор // Сибирские огни. 1922. № 5. С. 75-82.

18. Вейсберг Г.П., Пушкарев Г.М. Сибирь в художественной литературе. М.: Гос. изд-во, 1927. $307 \mathrm{c.}$

${ }^{1}$ «Сухой» итог первого десятилетия был подведен уже в собственно ойротском издании - в Улале (столица Ойротии) вышел политико-экономический сборник, посвященный периоду становления национальной автономии алтайцев [53]. 
19. Мухачев И. Чуйский тракт. Барнаул: Изд. В.М. Семенова-Трудового, 1926. $20 \mathrm{c}$.

20. Потанин Г.Н. В Чемальском тупике // Сиб. жизнь. 1910. № 142.

21. Эдоков Л. Ойротская автономная область. М.: Власть Советов, 1931. 72 с.

22. Коптелов А.Л. Золотые горы // Сиб. огни. 1927. № 3. С. 136-153.

23. Коптелов А.Л. Горными тропами // Сиб. огни. 1928. № 4. С. 125-149.

24. Кованов В. В горах Алтая: Всесоюзная пионерская экспедиция юных мичуринцев на Алтай. М.: Молодая гвардия, 1935. 64 с.

25. Коптелов А.Л. Морок // Сиб. огни. 1927. № 4. С. 19-69.

26. Чудакова М.О. Сквозь звезды к терниям. Смена литературных циклов // Новый мир. 1990. № 4. С. 242-262.

27. Гайлит К. Заметки о сибирской детской литературе // Сиб. огни. 1933. № 56. C. $150-156$.

28. Гайлит К.Н. Грозный перевал. Новосибирск, 1937. 186 с.

29. Коптелов А.Л. Дни и годы // Сиб. огни. 2000. № 6 [Электронный ресурс] // www.sibogni.ru/archiv/6/268

30. Гайлит К.Н. Грозный перевал: повесть. Барнаул: Алт. кн. изд-во, 1967. 224 с.

31. Сапожников В.В. Пути по русскому Алтаю. Новосибирск: Сибкрайиздат, 1926. $166 \mathrm{c}$.

32. Вся Сибирь с включением Уральской области: Справочная и адресная книга на 1925/1926 г. М.: Изв. ЦИК СССР и ВЦИК, 1925. 655 с.

33. Статистико-экономический обзор Киргизской Советской Социалистической Республики. Оренбург, 1923. 416 с.

34. Сапожников В.В. Пути по русскому Алтаю. Томск, 1912. 169 с.

35. Казанский П. Чемал - «Алтайская Ялта» // Сибирь. 1925. № 3. С. 11-13.

36. Шкапская М. В плетеном коробке // Шкапская М.В. Сама по себе. Л.: Изд-во писателей в Ленинграде, 1930. С. 267-288.

37. Потанин Г.Н. Выставка Гуркина // Сиб. жизнь. 1910. № 49.

38. Базанова Л. Выставка картин художника Гуркина // Сиб. жизнь. 1907. № 197-198; 1908. № 2.

39. Копьлов И.Л. На перевале: К первой Всесибирской передвижной выставке. Новосибирск: Сибкрайиздат, 1927. 18 с.

40. Потанин Г.Н. Инородцы Алтая // Живописная Россия: Отечество наше в его земельном, историческом, племенном, экономическом и бытовом значении / под общ. ред. П.П. Семенова. Т. 11 Западная Сибирь. СПб., 1884. С. 253-272.

41. Караваева А. Золотой клюв // Собр. соч. М.; Л.: Гос. изд-во, 1927. Т. 1. 327 с. 42. Хроника // Сиб. огни. 1930. № 3. С. 125.

43. Шатов Л.А. Золотой клюв: Фильм в 6 частях по одноименной повести Анны Караваевой. Сценарий и постановка Евг. Червякова [Либретто и методические указания к беседе]: В помощь политпросветработнику. М.: Теакинопечать, 1929. 8 с.

44. Потанин Г.Н. Алтай // Живописная Россия: Отечество наше в его земельном, историческом, племенном, экономическом и бытовом значении / под общ. ред. П.П. Семенова. Т. 11. Западная Сибирь. СПб., 1884. С. 193-224.

45. Штурм Белухи: сб. ст. участников альпиниады 1935 г. / под ред. Н.П. Ялухина, И.И. Долгих, Г.Н. Мухоедова. Новосибирск: Зап.-Сиб. краев. изд-во, 1936. $222 \mathrm{c}$.

46. Коптелов А.Л. Белуха: очерки. Новосибирск: Зап.-Сиб. краев. изд-во, $1936.60 \mathrm{c}$.

47. Коптелов А.Л. В горах Алтая. М.: Молодая гвардия, 1937. 137 с. 
48. Коптелов А.Л. Снежный пик: повесть. Новосибирск: ОГИЗ, 1947. 195 с.

49. Стонов Д. Повести об Алтае. М.: Федерация, 1930. 298 с.

50. Потанин Г.Н. Речь на чествовании 25 -летнего юбилея В.В. Сапожникова // Чествование 25-летнего юбилея В.В. Сапожникова. Томск, 1910. С. 2-6.

51. Чащина Л.Г. Русская литература Горного Алтая: Эволюция. Тенденции. Пути интеграции. Томск: Изд-во Том. ун-та, 2003. 252 с.

52. Потапов Л.П. Очерк истории Ойротии: Алтайцы в период русской колонизации. Новосибирск: ОГИЗ, 1933. 204 с.

53. Десять лет Советской Ойротии: политико-экономический сб. / под ред. Г. Чучкалова. Улала: Ойрот. обл. отд. ОГИЗ, 1932. 105 с.

G. PUSHKARYOV'S IN THE RANGES OF THE ALTAI AS A PROTOTYPE OF THE OIROT ENCYCLOPEDIA (SOME ASPECTS OF THE ARTISTIC-IDEOLOGICAL IMAGINATION OF SOVIET NATIONAL PERIPHERAL AREAS).

Imagology and Comparative Studies, 2014, 2, pp. 92-113. DOI 10.17223/24099554/2/6

Shastina Tatiana P. Gorno-Altaisk State University (Gorno-Altaisk, Russian Federation). E-mail: tshliteratura@mail.ru

Keywords: Oirotia, Russian literature of Siberia, travelogue, imagology, encyclopedism.

The article covers the book In the ranges of the Altai (1930) by Gleb Pushkaryov, one of the founders of The Siberian Writers' Union and one of the ideologists of Siberian Early Soviet literature which is the model of artistic-ideological imagination of Soviet national periphery (Oirot autonomous oblast - Oirotia). Created as a travelogue (three schoolboys travel throug h the Altai Mountains following the routes of V.V. Sapozhnikov and G.N. Potanin) and addressed to the teenage children, the book is considered to be an experience of a systemic summary of the knowledge of nature and ethnography of the newborn autonomy, a prototype of the Oirot encyclopedia. The literary context of this fictitious travelogue is interpreted as a re-discovery of the Altai Mountains which sets the new name, Oirotia, for the territory. Pushkaryov's viewpoint is interpreted as an opposition to such a "rediscovery" which consists in following the regional position in the creation of the images of Siberian non-residents and non-residential territories; this idea is emphasized by the geographical term "Altai" used in the title.

The book is interpreted as an attempt of the opposition to the rhetoric of the cultural retardation created by the Soviet national policy. The author of the article comes to a conclusion that the addressee choice allows Pushkaryov to avoid critical social problems, so he does not portray the authochtons ("the natives", "the Kalmyks") as the victims of the Tsarism colonial policy in the past and the Great Russian chauvinism at present, but speaks about them as of "the children of nature". At the beginning of his creative development, G. Pushkaryov wrote a series of micro-stories about the Altai peoples, "The infants of the Mountains" (1922).

Children's view on the world of the exotic nature of the Altai Mountains and the exotic "Kalmyks", an Altai people, balances these worlds naturally; adults' view (the teacher, the guides) separates these worlds assimilating the first one economically and almost leveling the second one ethnically. In the ranges of the Altai, the characters-travelers discover several worlds existing in parallel: the civilized world of the present, the exotic world of the natives, the fairy-tale world of natural resources along with fabulous bandits and Old Believers. The passage between the worlds is realized via the mountain passes - natural world boundaries. The natural-science component of the text bases on the geographical, 
botanical, zoological, entomological, and ethnographical scientific data collected mainly by the scientists of Tomsk State University in the late 19th - early 20th centuries. The latest information on the region is presented by statistics (deer-raising, beekeeping, hunting, wood floating etc.).

Pushkaryov's book is a manual typical for the outset of the Soviet study of local lore; it demonstrates the specifics of the national periphery description in the form of a fascinating journey around an exotic area.

\section{References}

1. Gordienko P.Ya. Oyrotiya [Oyrat]. Gorno-Altaysk: Ak-Chechek Publ., 1994. 141 p.

2. Konzychakov Sary-Sep L.A. Kul'turno-istoricheskiy ocherk ob altaytsakh: (k voprosu o vydelenii avtonomnoy oblasti "Oyrat" [The cultural and historical essay on the Altaian: (on the allocation of the autonomous region of Oyrat]. Sibirskie ogni, 1922, no. 1, pp. 109-115. 3. Anisimov K.V. Problemy poetiki literatury Sibiri XIX - nachala XX vv: Osobennosti stanovleniya i razvitiya regional'noy literaturnoy traditsii [Poetics of Siberian literature in the 19th - early 20th centuries. Features of formation and development of the regional literary tradition]. Tomsk: Tomsk State University Publ., 2005. 304 p.

4. Anisimov K.V. Paradigmatika i sintagmatika sibirskogo teksta russkoy literatury [The paradigmatic and syntagmatic text of Siberian text of Russian literature]. In: Kazarkin A. (ed.) Sibirskiy tekst v russkoy kul'ture [Siberian text in Russian culture]. Tomsk: Sibirika Publ., 2007, pp. 60-73.

5. Martin T. Imperiya "polozhitel'noy deyatel'nosti”. Natsii i natsionalizm v SSSR, 1923-1939 [The Empire of "positive activities". Nations and Nationalism in the USSR, 1923-1939]. Translated from English by O.R. Shchelokova. Moscow: ROSSPEN Publ., 2011. 855 p.

6. Shastina T.P. Mountain Altai in the essays of metropolitan journalists of the 1920s: Experience in representing the national margin. Zhurnalistskiy ezhegodnik - Journalist Yearbook, 2013, no. 2, pt. 1, pp. 43-47. (In Russian).

7. Ababkov I. Zor'ka [Dawn]. Moscow: Federatsiya Publ., 1931. 133 p.

8. Gzhitsky V.Z. Chernoe ozero [The Black Lake]. Translated from Ukranian by P. Opanasenko. Moscow; Leningrad: The State Publishing House, 1930. 344 p.

9. Chanskiy E. Zavarukha [Mess]. Moscow; Leningrad: Zemlya i fabrika Publ., 1930. 387 p.

10. Egart M. Pereprava: Altayskie ocherki [The Ferry: Altai essays]. Moscow; Leningrad: The State Publishing House, 1931. 196 p.

11. Mamet L.P. Oyrotiya: Ocherk natsional'no-osvoboditel'nogo dvizheniya i grazhdanskoy voyny na Gornom Altae [Oyrat: The national liberation movement and the civil war in the Altai Mountains]. Gorno-Altaysk: Ak Chechek Publ., 1994. 181 p.

12. Koptelov A.L. Velikoe kochev'e [The Great nomad]. Sibirkie ogni, 1934, no. 3, pp. 1-133.

13. Pushkarev G.M. V khrebtakh Altaya [In the Altai ranges]. Novosibirsk: Sibkrayizdat Publ., 1930. 71 p.

14. Respublika Altay: kratkaya entsiklopediya [The Republic of Altai. A Brief Encyclopeadia]. Novosibirsk: Arta Publ., 2010. 366 p.

15. Kim A.A. 120 let so dnya rozhdeniya pisatelya-prozaika Pushkareva Gleba Mikhaylovicha (1889-1961) [120 years since the birth of the writer and novelist Gleb Mikhailovich Pushkarev (1889-1961)]. Available at: http://www.ngonb.ru/ calendar/article.php?ar=55.

16. Anson A. (ed.) Sibirskaya nov': Khrestomatiya po istorii revolyutsionnogo dvizheniya v Sibiri za 10 let [The Siberian new soil: An anthology on the history of the revolutionary movement in Siberia for 10 years]. Novosibirsk: Sibkrayizdat Publ., 1927. 255 p. 
17. Pushkarev G.M. Mladentsy gor [Infants of the mountains]. Sibirskie ogni, 1922, no. 5, pp. 75-82.

18. Weisberg G.P., Pushkarev G.M. Sibir' v khudozhestvennoy literature [Siberia in fiction]. Moscow: The State Publishing House, 1927. 307 p.

19. Mukhachev I. Chuyskiy trakt [Chuya Highway]. Barnaul: V.M. Semenov-Trudovoy Publ., 1926. 20 p.

20. Potanin G.N. V Chemal'skom tupike [In Chemal deadlock]. Sibirskaya zhizn', 1910, no. 142. 21. Edokov L. Oyrotskaya avtonomnaya oblast' [Oyrat]. Moscow: Vlast' Sovetov Publ., 1931. $72 \mathrm{p}$.

22. Koptelov A.L. Zolotye gory [Golden Mountains]. Sibirskie ogni, 1927, no. 3, pp. 136-153.

23. Koptelov A.L. Gornymi tropami [Mountain trails]. Sibirskie ogni, 1928, no. 4, pp. 125149.

24. Kovanov V. V gorakh Altaya: Vsesoyuznaya pionerskaya ekspeditsiya yunykh michurintsev na Altay [In the Altai Mountains: The Union Pioneer expedition of Young Michurinists to the Altai]. Moscow: Molodaya gvardiya Publ., 1935. 64 p.

25. Koptelov A.L. Morok [Wraith]. Sibirskie ogni, 1927, no. 4, pp. 19-69.

26. Chudakova M.O. Skvoz' zvezdy k terniyam. Smena literaturnykh tsiklov [Through the stars to the thorns. The change of literary cycles]. Novyy mir, 1990, no. 4, pp. 242-262.

27. Gailit K. Zametki o sibirskoy detskoy literature [Notes on the Siberian literature for children]. Sibirskie ogni, 1933, no. 5-6, pp. 150-156.

28. Gailit K. Groznyy pereval [The terrible pass]. Novosibirsk, 1937. 186 p.

29. Koptelov A.L. Dni i gody [Days and years]. Sibirskie ogni, 2000, no. 6. Available at: www.sibogni.ru/archiv/6/268.

30. Gaylit K.N. Groznyy pereval [The terrible pass]. Barnaul: Altai Book Publ., 1967. 224 p.

31. Sapozhnikov V.V. Puti po russkomu Altayu [Ways to Russian Altai]. Novosibirsk: Sibkrayizdat Publ., 1926. 166 p.

32. Vsya Sibir's vklyucheniem Ural'skoy oblasti: Spravochnaya $i$ adresnaya kniga na 1925/1926 g. [All Siberia including the Urals: The Reference and Adress Book for 1925/1926]. Moscow: Izv. TsIK SSSR i VTsIK Publ., 1925. 655 p.

33. Statistiko-ekonomicheskiy obzor Kirgizskoy Sovetskoy Sotsialisticheskoy Respubliki [Statistical and economic overview of the Kirghiz Soviet Socialist Republic]. Orenburg, 1923. $416 \mathrm{p}$.

34. Sapozhnikov V.V. Puti po russkomu Altayu [Ways to Russian Altai]. Tomsk, 1912. 169 p.

35. Kazanskiy P. Chemal - "Altayskaya Yalta" [Chemal - "Yalta" of the Altai]. Sibir', 1925, no. 3, pp. 11-13.

36. Shkapskaya M. Sama po sebe [By myself]. Leningrad: Leningrad Writers Publ., 1930, pp. 267-288.

37. Potanin G.N. Vystavka Gurkina [The exhibition of Gurkin]. Sibirskaya zhizn', 1910, no. 49.

38. Bazanova L. Vystavka kartin khudozhnika Gurkina [The exhibition of the artist Gurkin]. Sibirskaya zhizn', 1907, nos. 197-198.

39. Kopylov I.L. Na perevale: K pervoy Vsesibirskoy peredvizhnoy vystavke [On the pass: The first All-Siberian traveling exhibition]. Novosibirsk: Sibkrayizdat Publ., 1927. 18 p.

40. Potanin G.N. Inorodtsy Altaya [The indigineous people of Altai]. In: Semenov P.P. (ed.) Zhivopisnaya Rossiya: Otechestvo nashe v ego zemel'nom, istoricheskom, plemennom, ekonomicheskom i bytovom znachenii [The picturesque Russia. Our homeland andn its land, history, tribes, economy and everyday]. St. Petersburg: Wolf Publ., 1884, vol. 11, pp. 253-272. 
41. Karavaeva A. Sobranie sochineniy [The collected works]. Moscow; Leningrad: The State Publishing House, 1927, vol. 1, 327 p.

42. Khronika [Chronicle]. Sibirskie ogni, 1930, no. 3, p. 125.

43. Shatov L.A. Zolotoy klyuv: Fil'm v 6 chastyakh po odnoimennoy povesti Anny Karavaevoy [The golden beak: Film in 6 parts by the novel of Anna Karavaeva]. Moscow: Teakinopechat' Publ., 1929. 8 s.

44. Potanin G.N. Altay [Altai]. In: Semenov P.P. (ed.) Zhivopisnaya Rossiya: Otechestvo nashe $v$ ego zemel'nom, istoricheskom, plemennom, ekonomicheskom i bytovom znachenii [The picturesque Russia. Our homeland andn its land, history, tribes, economy and everyday]. St. Petersburg: Wolf Publ., 1884, vol. 11, pp. 193-224.

45. Yalukhin N.P., Dolgikh I.I., Mukhoedov G.N. (eds.) Shturm Belukhi [Attacking Belukha]. Novosibirsk: West Siberian Book Publ., 1936. 222 p.

46. Koptelov A.L. Belukha: ocherki [Belukha. Essays]. Novosibirsk: West Siberian Book Publ., 1936. 60 p.

47. Koptelov A.L. V gorakh Altaya [In the Altai]. Moscow: Molodaya gvardiya Publ., 1937. $137 \mathrm{p}$.

48. Koptelov A.L. Snezhnyy pik [The snow-cald peak]. Novosibirsk: OGIZ Publ., 1947. 195 p

49. Stonov D. Povesti ob Altae [Tales of Altai]. Moscow: Federatsiya Publ., 1930. 298 p.

50. Potanin G.N. Rech' na chestvovanii 25-letnego yubileya V.V. Sapozhnikova [The speech at the celebration of the 25th anniversary of V.V. Sapozhnikov]. In: Chestvovanie 25-letnego yubileya V.V. Sapozhnikova [Honoring the 25th anniversary of V.V. Sapozhnikov]. Tomsk, 1910, pp. 2-6.

51. Chashchina L.G. Russkaya literatura Gornogo Altaya: Evolyutsiya. Tendentsii. Puti integratsii [Russian literature of Gornyy Altai. Evolution. Trends. Ways of integration]. Tomsk: Tomsk State University Publ., 2003. 252 p.

52. Potapov L.P. Ocherk istorii Oyrotii: Altaytsy v period russkoy kolonizatsii [The short history of Oyrat: the Altaians during the Russian colonization]. Novosibirsk: OGIZ Publ., 1933. 204 p.

53. Chuchkalov G. (ed.) Desyat' let Sovetskoy Oyrotii [Ten years of the Soviet Oyrat]. Ulala: OGIZ Publ., 1932. 105 p. 